\title{
Persepsi Siswa Terhadap Keterampilan Guru Dalam Pembelajaran Pendidikan Jasmani Olahraga Dan Kesehatan
}

\author{
Sepdiyatman ${ }^{1}$, Yaslindo ${ }^{2}$, Witarsyah ${ }^{3}$ \\ ${ }^{123}$ Fakultas Ilmu Keolahragaan, Universitas Negeri Padang, Indonesia.
}

E-mail: sepdiyatman@yahoo.co.id ${ }^{1}$, yaslindo ${ }^{2} @$ fik.unp.ac.id ${ }^{2}, \underline{\text { witarsyah@fik.unp.ac.id }}{ }^{3}$

\begin{abstract}
Abstrak
Penelitian ini merupakan jenis penelitian deskriptif yang bertujuan untuk mengetahui sejauhmana Persepsi Siswa Terhadap Keterampilan Guru Dalam Pembelajaran Pendidikan Jasmani Olahraga Dan Kesehatan Di SDN 10 Pasaman Aia Gadang Kecamatan Pasaman Kabupaten Pasaman Barat. Populasi pada penelitian ini adalah Siswa-Siswi SDN 10 Pasaman Aia Gadang Kecamatan Pasaman Kabupaten Pasaman Barat Tahun Ajaran 2010/2011 yang terdiri dari siswa kelas IV sebanyak 235 orang yang terdiri dari 98 siswa dan 135 siswi, kelas V sebanyak 204 orang yang terdiri dari 84 siswa dan 120 siswi serta kelas VI sebanyak 200 orang yang terdiri dari 84 siswa dan 116 siswi.

Total populasi keseluruhan adalah sebanyak 639 orang. Sampel dalam penelitian ini diambil $10 \%$ dari siswa-siswi kelas IV dan kelas V dengan menggunakan teknik Strata Stratified Purposive Random sampling yaitu siswa kelas IV sebanyak 24 orang yang terdiri dari 10 laki-laki dan 14 perempuan, kelas $\mathrm{V}$ sebanyak 20 orang yang terdiri dari 8 laki-laki dan 12 perempuan. Total keseluruhan 44 orang. Alat pengumpul data dilakukan dengan angket berskala Likert, sedangkan teknik analisis data menggunakan analisis deskriptif melalui tabulasi frekuensi.

Hasil analisis data terhadap masing-masing variabel ditemukan, persepsi siswa terhadap guru dalam membuka pembelajaran diklasifikasikan "Cukup" dengan perolehan persentase $(54,54 \%)$. Persepsi siswa terhadap guru dalam materi pembelajaran diklasifikasikan "Cukup" yaitu dengan perolehan persentase $(58,40 \%)$. Persepsi siswa terhadap guru dalam metode pembelajaran diklasifikasikan "Cukup" yaitu dengan perolehan persentase (52,98\%). Persepsi siswa terhadap guru dalam menutup pembelajaran diklasifikasikan "Cukup" dengan perolehan persentase (52,27\%).
\end{abstract}

Kata Kunci: Persepsi Siswa, Keterampilan Guru, Pembelajaran Penjasorkes

\begin{abstract}
This research is a type of descriptive research that aims to determine the extent of students' perceptions of teacher skills in learning physical sports and health education at SDN 10 Pasaman Aia Gadang, Pasaman, Pasaman Barat District. The population in this study were students of SDN 10 Pasaman Aia Gadang Pasaman District, West Pasaman Regency Academic Year 2010/2011 which consisted of class IV students totaling 235 people consisting of 98 students and 135 students, grade V totaling 204 people consisting of 84 students and 120 students as well as class VI as many as 200 people consisting of 84 students and 116 students.

The total population is 639 people. The sample in this study was taken $10 \%$ of students in class $I V$ and class $V$ using strata stratified purposive random sampling technique, namely class IV students as many as 24 people consisting of 10 men and 14 women, grade $V$ as many as 20 people consisting of 8 men and 12 women. In total 44 people. Data collection tools are carried out using a Likert scale questionnaire, while data analysis techniques use descriptive analysis through frequency tabulation.
\end{abstract}


Sport Science: Jurnal Sain Olahraga dan Pendidikan Jasmani ISSN 114-562X (Cetak), ISSN XXXX-XXXX(Online)

http://sportscience.ppj.unp.ac.id/index.php/jss/index

The results of data analysis of each variable found, students' perceptions of teachers in opening learning classified "Enough" with the acquisition of a percentage (54.54\%). Students' perceptions of teachers in learning material are classified as "Sufficient" ie by obtaining a percentage $(58.40 \%)$. Students' perceptions of teachers in learning methods are classified as "Sufficient", that is by obtaining a percentage (52.98\%). Students' perceptions of teachers in closing learning are classified as "Enough" with the percentage gain (52.27\%).

\section{Keywords: Student Perception, Teacher Skills, Penjasorkes Learning}

\section{PENDAHULUAN}

Proses pembelajaran pendidikan jasmani olahraga dan kesehatan merupakan aspek penting yang perlu diperhatikan adanya interaksi dua arah antara siswa dengan guru. Siswa sebagai warga belajar, dan guru sebagai sumber belajar. Dalam hal ini guru tidak hanya bertugas sebagai pengajar, akan tetapi juga mendidik. Artinya, guru harus mampu mentransfer nilai-nilai yang dimiliki kepada siswanya. Nilai-nilai tersebut harus dapat diwujudkan dalam bentuk tingkah laku sehari-hari.

Oleh sebab itu sangat dibutuhkan proses pembelajaran yang baik dari seorang guru pendidikan jasmani olahraga dan kesehatan yaitu memberikan kesempatan kepada peserta didik untuk terlibat langsung dalam berbagai pengalaman belajar melalui aktivitas jasmani, olahraga dan kesehatan yang terpilih yang dilakukan secara sistematis. Sebagai suatu sistem, pembelajaran pendidikan jasmani olahraga dan kesehatan akan dipengaruhi oleh berbagai komponen yang membentuknya. Menurut Sanjaya (2008:25) pembelajaran pendidikan jasmani olahraga dan kesehatan siswa di sekolah dipengaruhi oleh banyak faktor, diantaranya; Keterampilan guru pendidikan jasmani olahraga dan kesehatan, siswa, sarana dan prasarana serta faktor lingkungan.

Dalam pembelajaran pendidikan jasmani olahraga dan kesehatan di dalam kelas maupun di lapangan tidak lepas dari keterampilan dasar mengajar seperti yang dikemukakan di atas. Terlaksananya interaksi belajar mengajar antara guru dan siswa di tentukan oleh seberapa besar seorang guru menguasai keterampilan dasar mengajar yang dimiliki oleh seorang guru serta dilaksanakan dengan baik, maka akan memudahkan guru tersebut mengelola pengajaran itu sendiri hasil yang diperoleh akan sesuai dengan apa yang diinginkan.

Keterampilan dasar yang dimiliki guru pendidikan jasmani olahraga dan kesehatan, seharusnya menimbulkan motivasi siswa untuk mengikuti untuk mengikuti pelajaran penjasorkes dengan semangat, senang dan gembira sehingga pembelajaran penjasorkes dengan baik. Berdasarkan fenomena di lapangan dan wawancara dengan kepala sekolah di SDN 10 Pasaman Aia Gadang Kecamatan Pasaman Kabupaten Pasaman Barat, penulis menduga permasalahan yang timbul di lapangan sekarang adalah tidak efektifnya pembelajaran pendidikan jasmani olahraga dan kesehatan seperti keterampilan dalam membuka dan menutup pelajaran, menjelaskan pelajaran dan mengelola kelas.

Hal ini menyebabkan kurangnya perhatian siswa terhadap pembelajaran yang dilakukan oleh guru pendidikan jasmani seperti: siswa merasa bosan atau tidak sesuai dengan pola mengajar yang diterapkan guru, siswa memandang guru kurang menguasai bahan pelajaran yang sedang disajikan. Kemudian tidak efektifnya pengelolaan kelas yang dilakukan oleh guru pendidikan jasmani olahraga dan kesehatan seperti : masih ditemukannya siswa melakukan gerakan-gerakan fisik yang bersifat mengganggu terhadap siswa lain. Jika dibiarkan perilaku-perilaku tersebut, maka akan menimbulkan suasana yang tidak menyenangkan dalam pembelajaran pendidikan jasmani olahraga dan kesehatan. Selanjutnya akan berdampak terhadap hasil belajar yang diharapkan akan sulit untuk diraih.

Siswa merupakan lingkungan terdekat guru pendidikan jasmani olahraga dan kesehatan di sekolah yang memiliki berbagai persepsi tentang bagaimana pembelajaran pendidikan jasmani olahraga dan kesehatan di sekolah. Untuk itu perlu adanya penelitian secara ilmiah untuk mengetahui 


\section{Sport Science: Jurnal Sain Olahraga dan Pendidikan Jasmani ISSN 114-562X (Cetak), ISSN XXXX-XXXX(Online) http://sportscience.ppj.unp.ac.id/index.php/jss/index}

pembelajaran pendidikan jasmani olahraga dan kesehatan di SDN 10 Pasaman Aia Gadang Kecamatan Pasaman Kabupaten Pasaman Barat, Sehingga dari hasil penelitian ini bisa dilahirkan suatu kesimpulan yang bisa dijadikan langkah antisipatif bagi peningkatan hasil belajar siswa ke depan.

Persepsi seseorang terhadap dirinya sendiri sangat mempengaruhi pembentukan kesan Atas kepada orang lain. Persepsi sangat mempengaruhi pembentukan kesan Atas kepada orang lain atau orang asing yang ditemuinya. Dalam proses belajar mengajar agar tercapai guru hendaknya perlu mengetahui karakteristik kognitif siswa, karena karakter kognitif siswa dapat dipengaruhi oleh persepsi siswa-siswanya.

Guru pendidikan jasmani olahraga dan kesehatan merupakan orang yang secara langsung berhadapan dengan siswa. Pada sistem pembelajaran guru bisa berperan sebagai perencana (planer) atau desainer (designer) pembelajaran pendidikan jasmani olahraga dan kesehatan, sebagai implementator atau mungkin keduanya. Dalam pelaksanaan perannya sebagai implementator rencana dan desain pembelajaran guru pendidikan jasmani olahraga dan kesehatan bukanlah hanya berperan sebagai model atau teladan bagi siswa yang diajarnya akan tetapi juga sebagai pengelola pembelajaran (manager of learning) dan memiliki keterampilan yang baik dalam proses pembelajaran.

Keterampilan yang baik dalam proses pembelajaran guru pendidikan jasmani olahraga dan kesehatan akan terlihat dari keterampilan seorang guru dalam membuka dan menutup pelajaran, menjelaskan pelajaran dan mengelola kelas dengan baik agar terciptanya suasana pembelajaran yang kondusif. Pembelajaran pendidikan jasmani olahraga dan kesehatan merupakan serangkaian kegiatan guru dan siswa atas dasar hubungan timbal balik (interaksi), dimana peristiwa in berlangsung dalam situasi edukatif untuk mencapai tujuan pendidikan jasmani olahraga dan kesehatan.

Sesuai dengan tujuan pendidikan jasmani olahraga dan kesehatan yaitu membantu siswa agar memperoleh derajat kebugaran jasmani melalui banyak aktifitas gerak dalam bermain dan berolahraga sehingga terjadi perubahan pada jasmani, mental dan emosional siswa. Pembelajaran pendidikan jasmani olahraga dan kesehatan yang optimal dipengaruhi oleh bagaimana keterampilan menutup dan membuka pelajaran, keterampilan menjelaskan pelajaran dan keterampilan mengelola kelas. Oleh sebab itu dibutuhkan persepsi siswa agar dapat memberikan gambaran secara deskriptif mengenai pembelajaran pendidikan jasmani olahraga dan kesehatan di SDN 10 Pasaman Aia Gadang Kecamatan Pasaman Kabupaten Pasaman Barat

\section{METODE}

Merujuk dari pendapat ahli dan berdasarkan permasalahan yang akan dibahas dalam penelitian ini, maka Penelitian ini digolongkan dalam jenis penelitian deskriptif. Penelitian ini bertujuan untuk menggambarkan dan menafsirkan tentang Persepsi Siswa Terhadap Keterampilan Guru dalam Pembelajaran Pendidikan jasmani olahraga dan kesehatan di SDN 10 Pasaman Aia Gadang Kecamatan Pasaman Kabupaten Pasaman Barat.Sudjana (1989: 64) menyatakan "Penelitian Deskriptif merupakan Penelitian yang berusaha mendeskripsikan gejala, peristiwa, kejadian yang terjadi pada saat sekarang.

Penelitian Deskriptif mengambil masalah atau memusatkan perhatian kepada masalahmasalah aktual sebagaimana adanya pada saat Penelitian dilaksanakan". Penelitian dilaksanakan pada bulan Mei s/d Juni 2011, penelitian ini bertempat di SDN 10 Pasaman Aia Gadang Kecamatan Pasaman Kabupaten Pasaman Barat pada semester genap tahun ajaran 2010/2011. Populasi adalah seluruh data atau objek, individu, peristiwa yang menjadi perhatian penelitian dalam suatu ruang lingkup dan waktu kita tentukan.

Secara rinci oleh Arikunto (2002:108), menyatakan bahwa "populasi adalah keseluruhan objek penelitian yang terdiri dari manusia, benda- benda, hewan, tumbuh-tumbuhan, gejala-gejala, nilai test atau peristiwa-peristiwa sebagai sumber data yang memiliki karakteristik tertentu di dalam suatu penelitian". Dalam penelitian ini yang akan menjadi populasi adalah Siswa-Siswi SDN 10 Pasaman 
Sport Science: Jurnal Sain Olahraga dan Pendidikan Jasmani ISSN 114-562X (Cetak), ISSN XXXX-XXXX(Online)

http://sportscience.ppj.unp.ac.id/index.php/jss/index

Aia Gadang Kecamatan Pasaman Kabupaten Pasaman Barat Tahun Ajaran 2010/2011 yang terdiri dari siswa kelas IV sebanyak 235 orang yang terdiri dari 98 siswa dan 135 siswi, kelas V sebanyak 204 orang yang terdiri dari 84 siswa dan 120 siswi serta kelas VI sebanyak 200 orang yang terdiri dari 84 siswa dan 116 siswi. Total populasi keseluruhan adalah sebanyak 639 orang. Agar lebih jelasnya dapat dilihat pada table satu sebagai berikut:

Sampel penelitian adalah bagian dari populasi yang diambil dengan menggunakan cara-cara tertentu, sehubungan dengan pengambilan sampel ini maka Arikunto (2002:109) mengemukakan bahwa "suatu persoalan penting yang dihadapi seorang peneliti jika hendak mengadakan research sampling adalah, bagaimana dia dapat memperoleh sampel yang mewakili populasi." Seperti diketahui bahwa sampel penelitian merupakan sebagian dari populasi atas keseluruhan populasi penelitian. Menurut Arikunto (2002:110) Mengemukakan "Jika penelitian mempunyai beberapa ratus subjek dalam populasi, mereka dapat menentukan sampel kurang lebih $1015 \%$ atau $20-25 \%$ atau lebih dari jumlah populasinya". Dari pendapat diatas maka sampel dalam penelitian ini diambil $10 \%$ dari siswasiswi kelas IV dan V, sedangkan kelas VI tidak diambil karena mengikuti Ujian Akhir Nasional. Sampel diambil dengan menggunakan teknik Strata Stratified Purposive Random sampling, maka dengan demikian diperoleh sebanyak 44 orang untuk dijadikan sampel. Agar lebih jelasnya tentang jumlah sampel yang akan digunakan dapat dilihat pada tabel berikut yang menerangkan persentase dari seluruh jumlah kelas IV dan V yang dijadikan sampel.

Berdasarkan tabel dua dapat dikemukakan bahwa yang terpilih sebagai sampel dalam penelitian ini adalah siswa kelas IV sebanyak 24 orang yang terdiri dari 10 siswa dan 14 siswi, kelas $\mathrm{V}$ sebanyak 20 orang yang terdiri dari 8 siswa dan 12 siswi. Total sampel keseluruhan adalah sebanyak 44 orang.

\section{Teknik dan Alat Pengumpulan Data}

Agar memperoleh data yang diinginkan, maka Penulis menggunakan alat pengumpulan data adalah Angket atau Kuesioner, wawancara terbatas dan observasi langsung ke lapangan yang bertujuan untuk ricek. Angket merupakan daftar pertanyaan yang akan dijawab oleh responden, sedangkan wawancara dilakukan secara terbatas dengan siswa dan observasi dilakukan di lingkungan SDN 10 Pasaman Aia Gadang Kecamatan Pasaman Kabupaten Pasaman Barat..

Dalam penyusunan angket terdapat juga pertanyaan yang mengarah pada pertanyaan positif dan negatif. Penulis menyusun angket penelitian yang diarahkan oleh dosen pembimbing. Kemudian menyebarkan angket kepada responden untuk memperoleh data Persepsi Siswa Terhadap Keterampilan Guru dalam Pembelajaran Pendidikan jasmani olahraga dan kesehatan di SDN 10 Pasaman Aia Gadang Kecamatan Pasaman Kabupaten Pasaman Barat.

Penyusunan Angket dilakukan berdasarkan Skala Likert dengan empat (4) kategori jawaban adalah sebagai berikut : Selalu (S), Sering (SR), Jarang (JR), Tidak Ada (TA). Jawaban dari angket berupa data kualitatif yang kemudian diubah menjadi bentuk data kuantitatif dalam bentuk pertanyaan atau pernyataan positif $(+)$ adalah Selalu $(S)=4$, Sering $(S R)=3$, Tidak Jarang $(J R)=2$ dan Tidak Ada $(\mathrm{TA})=1$. Sedangkan pertanyaan atau pernyataan negatif $(-)$ adalah : Selalu $(\mathrm{S})=1$, Sering $(\mathrm{SR})=$ 2 , Jarang $(\mathrm{JR})=3$ dan Tidak Ada $(\mathrm{TA})=4$.

Setelah pengolahan data nantinya, angka tersebut diubah lagi menjadi data kualitatif untuk memudahkan dalam pembahasan dimana untuk pertanyaan atau pernyataan bernilai positif $(+)$ adalah : Selalu $(S)=4$, Sering $(S R)=3$, Tidak Jarang $(J R)=2$ dan Tidak Ada $(T A)=1$. Sedangkan pertanyaan atau pernyataan negatif $(-)$ adalah : Selalu $(S)=1$, Sering $(S R)=2$, Jarang $(J R)=3$ dan Tidak Ada $(\mathrm{TA})=4$. Angket disusun berdasarkan beberapa langkah-langkah adalah sebagai berikut :

1.Membuat kisi-kisi.

2.Menetapkan indikator-indikator dari setiap variabel yang akan diteliti.

3.Merumuskan pernyataan (item) dari setiap indikator.

4.Mengkonsultasikan pernyataan tersebut kepada Dosen Pembimbing. 
Setelah semua data berhasil dikumpulkan kemudian diolah, karena jenis penelitian ini bersifat deskriptif maka teknik analisis yang dapat digunakan adalah dengan menggunakan teknik distribusi frekwensi (statistik deskriptif) dengan perhitungan persentase, seperti dijelaskan Sudidjono (1991:40): "Bila suatu penelitian bertujuan mendapatkan gambaran atau menemukan sesuatu sebagaimana adanya tentang sesuatu objek yang diteliti maka teknik analisis yang dibutuhkan cukup dengan perhitungan persentase".

\begin{tabular}{|c|c|c|}
\hline \multicolumn{2}{|c|}{ Kategori nilai rata-rata } \\
\hline No & Persentase (\%) & Klasifikasi \\
\hline 2 & $81-100$ & Baik sekali \\
\hline 3 & $61-80$ & Baik \\
\hline 4 & $41-60$ & Sedang \\
\hline 5 & $21-40$ & Kurang \\
\hline
\end{tabular}

Sumber : Ebel, R.L dan Frisbie, DA. 1972. Essentials of Education Measurement. New York : Prentice Hall

\section{HASIL DAN PEMBAHASAN \\ Hasil Penelitian}

Pada bab ini dilakukan analisis data tentang informasi yang diperoleh dari responden yakni secara berurutan mengenai: (1) deskripsi data dari masing-masing sub indikator "Persepsi Siswa Terhadap Keterampilan Guru dalam Pembelajaran Pendidikan Jasmani Olahraga dan Kesehatan di SDN 10 Pasaman Aia Gadang Kecamatan Pasaman Kabupaten Pasaman Barat ", (2) Pembahasan guna membahas informasi yang diperoleh dari responden.

Dalam analisis ini semua data yang sudah terkumpul, diolah dan dianalisa sesuai dengan cara dan ketentuan yang telah dikemukakan pada bab yang terdahulu, berikut ini akan dianalisis permasalahan yang dijumpai dalam penelitian ini secara berurutan mengenai Persepsi Siswa Terhadap Keterampilan Guru Dalam Pembelajaran Pendidikan Jasmani Olahraga dan Kesehatan di SDN 10 Pasaman Aia Gadang Kecamatan Pasaman Kabupaten Pasaman Barat, antara lain:

\section{Membuka Pelajaran}

Data tentang Persepsi Siswa Terhadap Keterampilan Guru dalam Pembelajaran Pendidikan Jasmani Olahraga dan Kesehatan di SDN 10 Pasaman Aia Gadang Kecamatan Pasaman Kabupaten Pasaman Barat, dengan variabel membuka pelajaran terdiri dari 44 orang siswa sebagai responden dan 8 item pernyataan. Dan data dikelompokkan masing-masing jawaban berdasarkan nilai skor, dan data dihitung persentasenya, maka dapat dibuat rangkuman distribusi frekwensi Persepsi Siswa Terhadap Keterampilan Guru Dalam Pembelajaran Pendidikan Jasmani Olahraga dan Kesehatan di SDN 10 Pasaman Aia Gadang Kabupaten Pasaman Barat dengan variabel membuka pelajaran.

Dapat dijelaskan bahwa 8 butir pernyataan 1- 8 yang dijawab responden sebanyak 44 orang, di mana masing-masing item terdiri dari 4 kategori, maka dapat diketahui sebanyak 111 kali dengan persentase $(31,53 \%)$ responden menjawab pernyataan dari variabel membuka pelajaran dengan selalu (SL) pada poin 4. Sebanyak 140 kali dengan persentase $(39,77 \%)$ responden menjawab pernyataan dari variabel membuka pelajaran dengan sering (SR) pada poin 3. Sebanyak 75 kali dengan persentase $(21,34 \%)$ responden menjawab pernyataan dari variabel membuka pelajaran dengan sekali-sekali (SS) pada poin 2. Sebanyak 26 orang dengan persentase (7,39\%) responden menjawab pernyataan dari variabel membuka pelajaran dengan tidak ada (TA) pada poin 1. Rata-rata nilai skor tertinggi pada pernyataan dari variabel membuka pelajaran dalam 
kategori sering (SR) dengan jumlah persentase $(39,77 \%)$, dengan demikian dapat dikatakan bahwa membuka pelajaran penjasorkes termasuk dalam kategori "Kurang", yaitu jumlah jawaban responden sebanyak 140 kali (39,77\%). Agar lebih jelasnya dapat digambarkan dengan grafik atau gambar berikut ini:

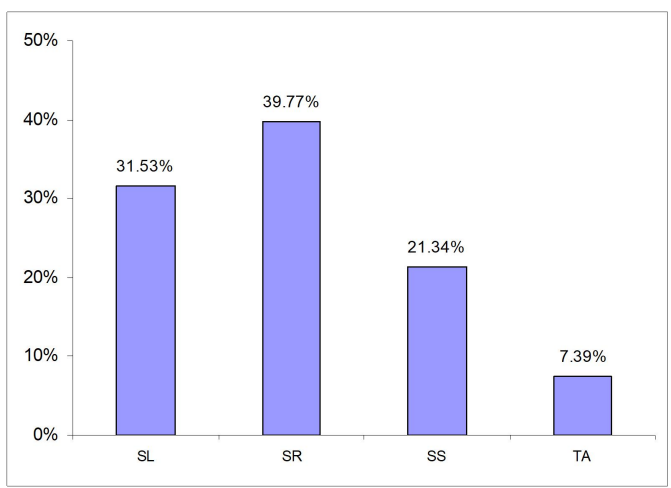

\section{Menjelaskan pelajaran}

Gambar 2. Grafik Persepsi pada guru dalam membuka pelajaran

Data tentang Persepsi Siswa Terhadap Keterampilan Guru Dalam Pembelajaran Pendidikan Jasmani Olahraga dan Kesehatan di SDN 10 Pasaman Aia Gadang Kecamatan Pasaman Kabupaten Pasaman Barat, dengan variabel menjelaskan pelajaran terdiri dari 44 orang siswa sebagai responden dan 9 item pernyataan. Data dikelompokkan masing-masing jawaban berdasarkan nilai skor, dan data di hitung persentasenya, maka dapat dibuat rangkuman distribusi frekwensi Persepsi Siswa Terhadap Keterampilan Guru Dalam Pembelajaran Pendidikan Jasmani Olahraga dan Kesehatan di SDN 10 Pasaman Aia Gadang Kecamatan Pasaman Kabupaten Pasaman Barat dengan variabel menjelaskan pelajaran. Maka didapatkan hasil penelitian bahwa 9 butir pernyataan 9 - 17 yang dijawab responden sebanyak 44 orang, di mana masing-masing item terdiri dari 4 kategori, maka dapat diketahui sebanyak 107 kali dengan persentase $(27,02 \%)$ responden menjawab pernyataan dari variabel menjelaskan pelajaran dengan selalu (SL) pada poin 4.

Sebanyak 118 kali dengan persentase $(29,80 \%)$ responden menjawab pernyataan dari variabel menjelaskan pelajaran dengan sering (SR) pada poin 3. Sebanyak 90 orang dengan persentase $(24,70 \%)$ responden menjawab pernyataan dari variabel menjelaskan pelajaran dengan sekali-sekali (SS) pada poin 2. Sebanyak 58 orang dengan persentase (14,62\%) responden menjawab pernyataan dari variabel menjelaskan pelajaran dengan tidak ada (TA) pada poin 1.

Rata-rata nilai skor tertinggi pada pernyataan dari variabel menjelaskan pelajaran dalam kategori sering (SR) dengan jumlah persentase $(29,80 \%)$, dengan demikian dapat dikatakan bahwa menjelaskan pelajaran penjasorkes termasuk dalam kategori "kurang", yaitu jumlah jawaban responden sebanyak 118 kali $(29,80 \%)$. Agar lebih jelasnya dapat digambarkan dengan grafik atau gambar berikut ini: 

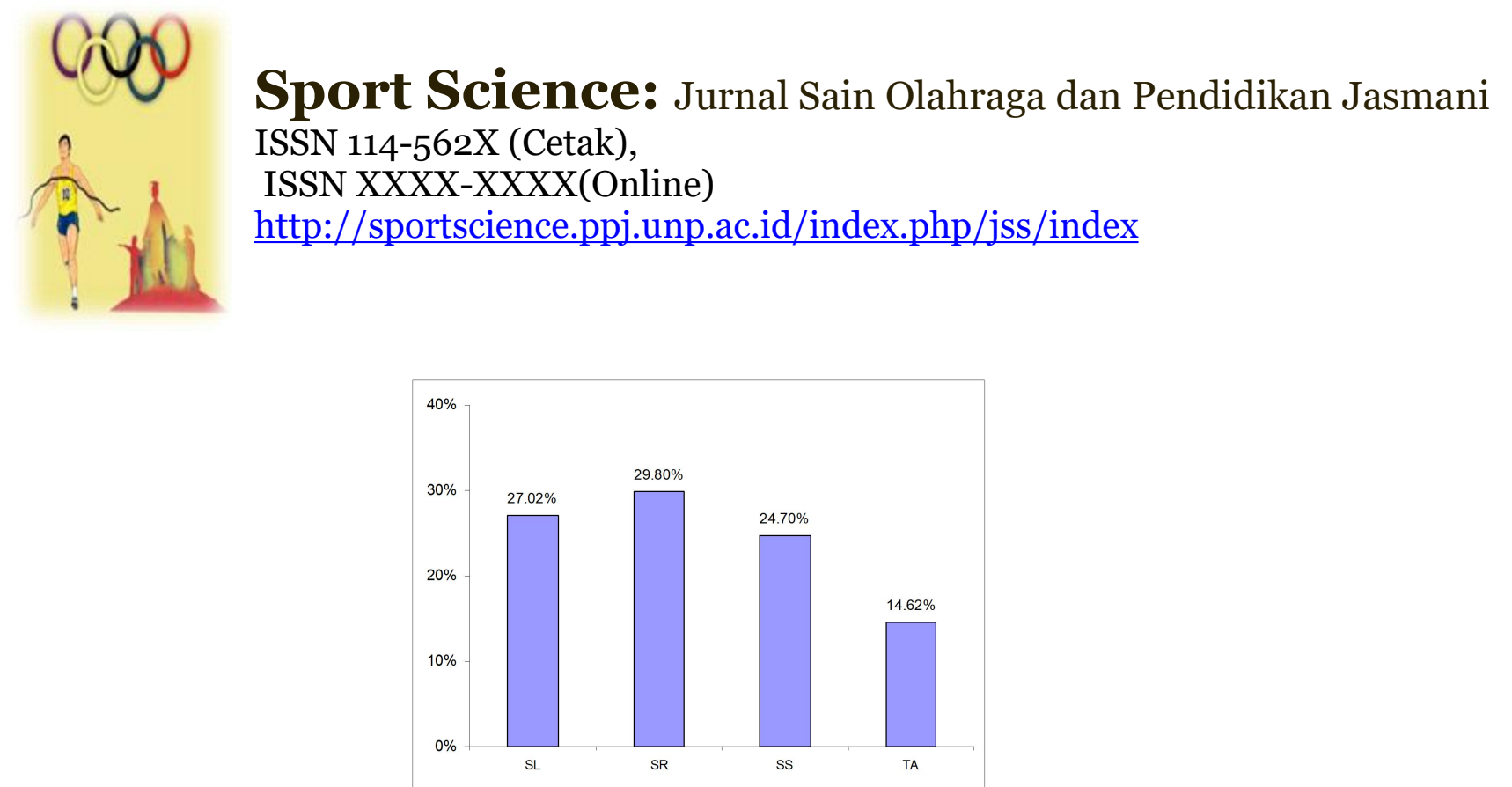

Gambar 3. Grafik Persepsi pada guru dalam menjelaskan pelajaran

\section{Mengelola kelas}

Data tentang Persepsi Siswa Terhadap Keterampilan Guru Dalam Pembelajaran Pendidikan Jasmani Olahraga dan Kesehatan di SDN 10 Pasaman Aia Gadang Kecamatan Pasaman Kabupaten Pasaman Barat, dengan variabel mengelola kelas terdiri dari 44 orang siswa sebagai responden dan 10 item pernyataan. Data dikelompokkan masing-masing jawaban berdasarkan nilai skor, dan data di hitung persentasenya, maka dapat dibuat rangkuman distribusi frekwensi Persepsi Siswa Terhadap Keterampilan Guru Dalam Pembelajaran Pendidikan Jasmani Olahraga dan Kesehatan di SDN 10 Pasaman Aia Gadang Kecamatan Pasaman Kabupaten Pasaman Barat dengan variabel mengelola

Dapat dijelaskan bahwa 10 butir pernyataan 18 - 27 yang dijawab responden sebanyak 44 orang, di mana masing-masing item terdiri dari 4 kategori, maka dapat diketahui sebanyak 156 kali dengan persentase $(35,45 \%)$ responden menjawab pernyataan dari variabel mengelola kelas dengan selalu (SL) pada poin 4, sebanyak 131 kali dengan persentase $(29,77 \%)$ responden menjawab pernyataan dari variabel mengelola kelas dengan sering (SR) pada poin 3, sebanyak 94 kali dengan persentase $(21,36 \%)$ responden menjawab pernyataan dari variabel mengelola kelas dengan sering (SS) pada poin 2, sebanyak 63 kali dengan persentase $(14,31 \%)$ responden menjawab pernyataan dari variabel mengelola kelas dengan tidak ada (TA) pada poin 1. Rata-rata nilai skor tertinggi pada pernyataan dari variabel mengelola kelas dalam kategori selalu (SL) dengan jumlah persentase $(35,45 \%)$, dengan demikian dapat dikatakan bahwa mengelola kelas penjasorkes termasuk dalam kategori "kurang", yaitu jumlah jawaban responden sebanyak 156 kali (35,45\%). Agar lebih jelasnya dapat digambarkan dengan grafik atau gambar 3 berikut ini:

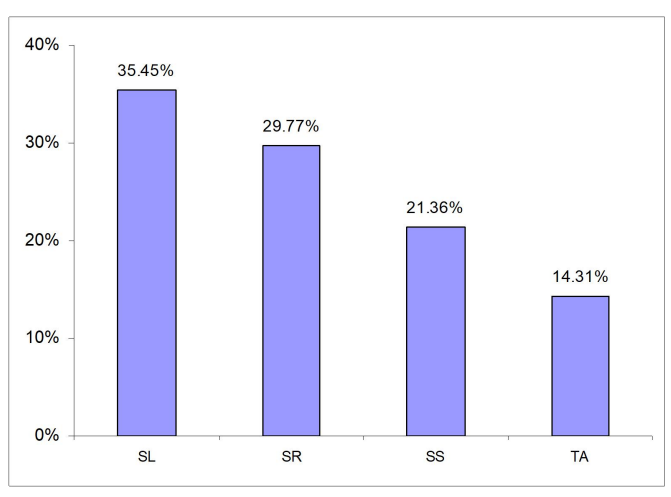




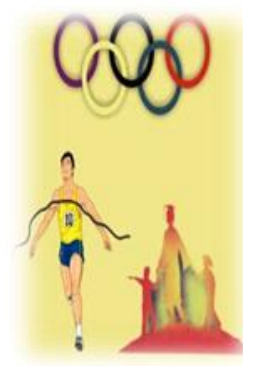

Sport Science: Jurnal Sain Olahraga dan Pendidikan Jasmani

ISSN 114-562X (Cetak),

ISSN XXXX-XXXX(Online)

http://sportscience.ppj.unp.ac.id/index.php/jss/index

Gambar 4. Grafik Persepsi pada guru dalam mengelola kelas

\section{Menutup Pelajaran}

Data tentang Persepsi Siswa Terhadap Keterampilan Guru Dalam Pembelajaran Pendidikan Jasmani Olahraga dan Kesehatan di SDN 10 Pasaman Aia Gadang Kecamatan Pasaman Kabupaten Pasaman Barat dengan variabel menutup pelajaran terdiri dari 44 orang siswa sebagai responden dan 3 item pernyataan. Data dikelompokkan masing-masing jawaban berdasarkan nilai skor, dan data di hitung persentasenya, maka dapat dibuat rangkuman distribusi frekwensi Persepsi Siswa Terhadap Keterampilan Guru Dalam Pembelajaran Pendidikan Jasmani Olahraga dan Kesehatan di SDN 10 Pasaman Aia Gadang Kecamatan Pasaman Kabupaten Pasaman Barat dengan variabel menutup.

Selanjutnya dapat dijelaskan bahwa 3 butir pernyataan 28-30 yang dijawab responden sebanyak 44 orang, di mana masing-masing item terdiri dari 4 kategori, maka dapat diketahui sebanyak 25 kali dengan persentase $(18,94 \%)$ responden menjawab pernyataan dari variabel menutup pelajaran dengan selalu (SL) pada poin 4. Sebanyak 39 kali dengan persentase (29,55\%) responden menjawab pernyataan dari penggunaan variabel menutup pelajaran dengan sering pada poin 3 , sebanyak 28 kali dengan persentase (14,96\%) responden menjawab pernyataan dari variabel menutup pelajaran dengan sekali-sekali (SS) pada poin 2, sebanyak 25 kali dengan persentase $(15,15 \%)$ responden menjawab pernyataan dari variabel menutup pelajaran dengan tidak ada (TA) pada poin 1 . Rata-rata nilai skor tertinggi pada pernysataan dari variabel menutup pelajaran dalam kategori sering (SR) dengan jumlah persentase (29,55\%), dengan demikian dapat dikatakan bahwa menutup pelajaran penjasorkes termasuk dalam kategori "kurang", yaitu jumlah jawaban responden sebanyak 39 kali $(29,55 \%)$. Agar lebih jelasnya dapat digambarkan dengan grafik atau gambar 4 berikut ini:

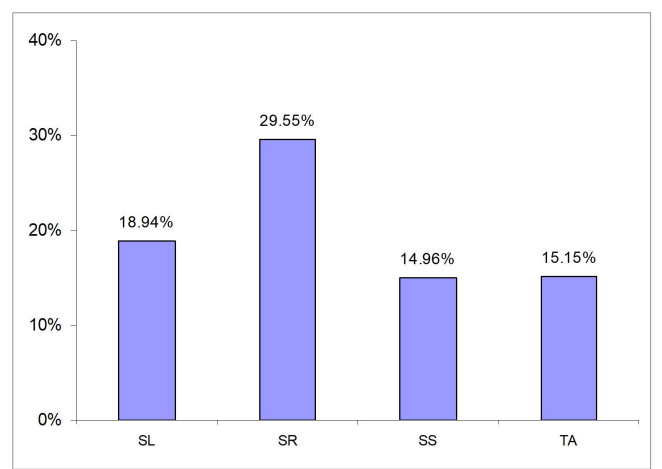

Gambar 5. Grafik Persepsi pada guru dalam menutup pelajaran

\section{B. Pembahasan}

Dari data yang diperoleh pada analisis deskriptif, terdapat beberapa hal indikator-indikator yang berpengaruh pada "Persepsi Siswa Terhadap Keterampilan Guru Dalam Pembelajaran Pendidikan Jasmani Olahraga dan Kesehatan di SDN 10 Pasaman Aia Gadang Kecamatan Pasaman Kabupaten Pasaman Barat". Oleh karena itu perlu adanya pembahasan indikator-indikator tersebut yang akan dijelaskan satu persatu dengan yang ada, sebagai berikut:

\section{Membuka Pelajaran}


Dalam proses belajar mengajar pendidikan jasmani dan kesehatan keterampilan membuka pelajaran merupakan salah satu faktor penting yang harus dikuasai guru. Sebab dengan adanya keterampilan membuka pelajaran akan dapat lebih mengarahkan siswa kepada pelaksanaan pembelajaran berikutnya, terlebih lagi peiaksanaan pengajaran dilakukan di lapangan yang mana banyak faktor mengganggu perhatian siswa.

Agar pelajaran pendidikan jasmani olahraga dan kesehatan tetap pada suasana yang dinamis, guru perlu merumuskan dengan jelas tujuan apa yang ingin dicapainya dan hal ini dicerminkan dalam metode membuka pelajaran. Apabila guru menguasai materi pelajaran diharuskan juga menguasai metode pengajaran sesuai kebutuhan materi ajar yang mengacu pada prinsip pedagogik yaitu memahami karakteristik peserta didik. Dengan memperhatikan metode membuka pelajaran, maka materi pelajaran akan terealisasi dengan baik.

Dari hasil analisis data dan deskripsi hasil penelitian tentang "Persepsi Siswa Terhadap Keterampilan Guru Dalam Pembelajaran Pendidikan Jasmani Olahraga dan Kesehatan di SDN 10 Pasaman Aia Gadang Kecamatan Pasaman Kabupaten Pasaman Barat dengan sub variabel membuka pelajaran, diperoleh Scor Capaian Responden (SCR) adalah 768 (54,54\%) termasuk dalam kategori “Cukup", artinya perumusan tujuan pembelajaran belum tercapai dengan baik sekali.

Tujuan akhir dari pendidikan jasmani adalah gerakan atau keterampilan yang memiliki siswa melalui proses kegiatan aktifitas manusia. Psikomotor merupakan tujuan utama dalam pembelajaran pendidikan jasmani. Oleh sebab itu, guru sebagai seseorang yang memiliki potensi dan kemampuan membuka pelajaran, dituntut untuk mampu melaksanakan pembelajaran yang meliputi persiapan alat, mengambil absen, memimpin stretching, memberikan permainan kecil, ringkasan teori yang diajarkan, pemberian informasi langkah-langkah tentang apa yang akan dilakukan siswa, pengajuan pertanyaan dan mereview materi minggu lalu.

\section{Menjelaskan Pelajaran}

Untuk meningkatkan efektif proses pembelajaran, guru harus dapat menjelaskan pelajaran dengan baik, agar tujuan pembelajaran dapat tercapai dengan baik. Apabila guru dapat menjelaskan pelajaran dengan baik, maka materi pelajaran yang dibutuhkan untuk kegiatan siswa akan dapat terlaksana dengan baik. Agar bahan pelajaran dapat disajikan dalam kegiatan siswa, guru harus mampu menjelaskan pelajaran yang dibuat sebelumnya, sehingga siswa memahami kegiatan yang akan dilakukan untuk mencapai tujuan pembelajaran. Tiap guru harus mampu menjelaskan pelajaran sebelum ia dengan penuh tanggung jawab dapat memasuki kelas, sebab mengajar merupakan tugas yang begitu kompleks dan sulit, sehingga tidak dapat dilakukan dengan baik oleh siapa pun tanpa persiapan untuk menjelaskan pelajaran.

Adapun bahan yang akan diajarkan kepada anak adalah apa-apa yang tertera di dalam kurikulum. Secara umum dapat dijelaskan bahwa aspek atau materi yang tertera di dalam kurikulum pendidikan jasmani olahraga dan kesehatan antara lain adalah :

a. Permainan dan olahraga 
Yang berhubungan dengan permainan dan olahraga yang meliputi: olahraga tradisional, kasti, softball, base ball, sepakbola, bolavoli, bolabasket, tenis meja, bulu tangkis, bela diri dan atletik.

b. Aktivitas Pengembangan

Yang berhubungan dengan aktivitas pengembangan adalah : komponenkebugaran jasmani.

c. Akitivitas senam/uji diri

Yang berhubungan dengan aktivitas senam/uji diri: senam lantai, ketangkasan tanpa alat, ketangkasan dengan alat, aktivitas lainnya.

d. Akitivas Ritmik

Aktivitas ritmik ini meliputi: senam pagi Indonesia, Senam kesegaran jasmani, Senam aerobik.

e. Aktivitas Air/Akuatik

Aktivitas ini meliputi: Keselamatan di air, Ketangkasan di air, renang.

f. Pendidikan Luar Kelas

Pendidikan luar kelas antara lain adalah: pengenalan lingkungan, berkemah, menjelajah, mendaki gunung dan aktivitas lainya.

Dari hasil analisis data dan deskripsi hasil penelitian tentang "Persepsi Siswa Terhadap Keterampilan Guru Dalam Pembelajaran Pendidikan Jasmani Olahraga dan Kesehatan di SDN 10 Pasaman Aia Gadang Kecamatan Pasaman Kabupaten Pasaman Barat dengan sub variabel menjelaskan pelajaran, diperoleh Scor Capaian Responden (SCR) adalah 925 (58,40\%) termasuk dalam kategori "Cukup", artinya perumusan tujuan pembelajaran belum tercapai dengan baik sekali.

\section{Mengelola Kelas}

Dalam pembelajaran proses belajar mengajar guru dituntut mencapai tujuan pengajaran dengan sebaik-baiknya. Untuk mendorong keberhasilan pengajaran hal penting untuk diketahui oleh guru adalah metode apa yang cocok digunakan untuk mengelola kelas dengan baik. Menurut Slameto (2003:201) mengemukakan, "Hal yang penting dalam metode ialah bagaimana mengelola kelas bertalian dengan tujuan belajar yang dicapainya".

Dari hasil analisis data dan deskripsi hasil penelitian tentang "Persepsi Siswa Terhadap Keterampilan Guru dalam Pembelajaran Pendidikan Jasmani Olahraga dan Kesehatan di SDN 10 Pasaman Aia Gadang Kecamatan Pasaman Kabupaten Pasaman Barat dengan sub variabel mengelola kelas, diperoleh Scor Capaian Responden (SCR) adalah 1038 (58,98\%) termasuk dalam kategori "Cukup", artinya perumusan tujuan pembelajaran belum tercapai dengan baik sekali.

Jadi, mengelola kelas dirancang sesuai dengan tujuan yang ingin dicapai dan dapat mendorong siswa untuk beraktivitas sesuai dengan gaya belajarnya. Oleh sebab itu, guru sebagai seseorang yang memiliki potensi dan kemampuan dalam pembelajaran, dituntut untuk mampu mengelola kelas dengan sebaik mungkin agar tujuan pembelajaran dapat tercapai secara efektif dan efesien, seperti; membagi perhatian, mengatur posisi atau tempat, memberi petunjuk.

\section{Menutup Pelajaran}

Keterampilan menutup peiajaran adalah kegiatan yang dilakukan guru untuk mengakhiri pelajaran atau kegiatan pembelajaran dengan mengemukakan kembali pokok-pokok pelajaran yang berfungsi untuk memberikan gambaran menyeluruh tentang apa yang telah dipelajari dan mengetahui keberhasilan siswa dalam menyerap pelajaran dan menentukan titik pangkal untuk pelajaran berikutnya. Salah satu usaha yang dapat dilakukan oleh guru sebelum menutup pelajaran adalah dengan melakukan evaluasi. 
Selanjutnya Depdikbud (1989:14) mengemukakan bahwa dari sudut pengajaran evaluasi adalah proses yang sistematis dalam menentukan sejauh mana tujuan intruksional dicapai oleh siswa (hasil belajar yang dicapai). Jadi, evaluasi dilakukan untuk mengetahui tingkat ketuntasan peserta didik yang telah menguasai kompetensi dasar. Evaluasi belajar yang dimaksudkan adalah evaluasi dalam implementasi pendidikan jasmani yang dilakukan dengan berbagai penilaian.

Dari hasil analisis data dan deskripsi hasil penelitian tentang "Persepsi Siswa Terhadap Keterampilan Guru dalam Pembelajaran Pendidikan Jasmani Olahraga dan Kesehatan di SDN 10 Pasaman Aia Gadang Kecamatan Pasaman Kabupaten Pasaman Barat dengan sub variabel mengelola kelas, diperoleh Scor Capaian Responden (SCR) adalah 276 (52,27\%) termasuk dalam kategori "Cukup", artinya kegiatan dalam menutup pelajaran yang dilakukan guru penjasorkes belum tercapai dengan baik sekali. Evaluasi atau suatu penilaian merupakan tugas lanjutan guru untuk menilai apakah tujuan, kemajuan dalam menerima pelajaran dan hasil belajar di kelas telah tercapai oleh siswa. Penilaian yang dilakukan guru penjasorkes dilihat dengan menguji siswa dalam melaksanakan gerakan-gerakan yang telah dipelajarinya dan bagaimana siswa mengembangkan gerakan tersebut dan hal ini dilakukan pada saat menutup pelajaran.

Penilaian diambil dengan menggunakan laporan hasil pengamatan guru disetiap akhir pelajaran. Dengan adanya lembar pengamatan tersebut memudahkan guru dalam memberikan penilaian yang objektif karena pengamatan tersebut dan nilai yang diperoleh siswa dapat dijadikan sebagai patokan keberhasilan siswa. Oleh sebab itu penting kiranya suatu proses pembelajaran pendidikan jasmani dilakukan evaluasi sebelum menutup pelajaran.

\section{KESIMPULAN}

Berdasarkan hasil penelitian tentang "Persepsi Siswa Terhadap Keterampilan Guru Dalam Pembelajaran Pendidikan Jasmani Olahraga dan Kesehatan di SDN 10 Pasaman Aia Gadang Kecamatan Pasaman Kabupaten Pasaman Barat". Maka dapat disimpulkan ; Dari hasil analisis data dan deskripsi hasil penelitian tentang Persepsi Siswa Terhadap Keterampilan Guru Dalam Pembelajaran Pendidikan Jasmani Olahraga dan Kesehatan di SDN 10 Pasaman Aia Gadang Kecamatan Pasaman Kabupaten Pasaman Barat dengan sub variabel membuka pembelajaran diklasifikasikan "Cukup" dengan perolehan persentase (55,54\%).

Dari hasil analisis data dan deskripsi hasil penelitian tentang Persepsi Siswa Terhadap Keterampilan Guru Dalam Pembelajaran Pendidikan Jasmani Olahraga dan Kesehatan di SDN 10 Pasaman Aia Gadang Kecamatan Pasaman Kabupaten Pasaman Barat dengan sub variabel materi pembelajaran diklasifikasikan "Cukup" yaitu dengan perolehan persentase $(58,40 \%)$; Dari hasil analisis data dan deskripsi hasil penelitian tentang Persepsi Siswa Terhadap Keterampilan Guru Dalam Pembelajaran Pendidikan Jasmani Olahraga dan Kesehatan di SDN 10 Pasaman Aia Gadang Kecamatan Pasaman Kabupaten Pasaman Barat dengan sub variabel metode pembelajaran diklasifikasikan "Cukup" yaitu dengan perolehan persentase (58,98\%).

Dari hasil analisis data dan deskripsi hasil penelitian tentang Persepsi Siswa Terhadap Keterampilan Guru Dalam Pembelajaran Pendidikan Jasmani Olahraga dan Kesehatan di SDN 10 Pasaman Aia Gadang Kecamatan Pasaman Kabupaten Pasaman Barat dengan sub variabel media/alat pembelajaran diklasifikasikan “Cukup” yaitu dengan perolehan persentase $(52,27 \%)$.

\section{DAFTAR RUJUKAN}

Abizar. (1995). Strategi Instruksional. Padang : IKP Padang Press 
Sport Science: Jurnal Sain Olahraga dan Pendidikan Jasmani ISSN 114-562X (Cetak), ISSN XXXX-XXXX(Online)

http://sportscience.ppj.unp.ac.id/index.php/jss/index

Abdoellah, Arma. 1998. Evaluasi Dalam Pendidikan Jasmani. Jakarta : Dirjen Pendidikan tinggi, Depdikbud.

Arikunto, Suharsimi. 1993. Manajemen Pengajaran. Jakarta : Rineka Cipta.

Bafirman. 1999. Sport Medicine. Padang : FIK UNP

Cooper, Kenneth. H. 1983. Aerobic. Terjemahan Antonius Adiwiyoto. Jakarta : Gramedia

Davies. Ivor. K. 1991. Pengelolaan Belajar. Jakarta : Rajawali Press

Depdikbud 1993. Pedoman Guru Olahraga. Jakarta : Depdikbud

Depdiknas. 2002. Ketahuilah Tingkat Kesegaran Jasmani Anda. Jakarta : Depdiknas Pusat Pengembangan Kwalitas Jasmani.

Dwijowinoto, Kasiyo. (1993). Dasar Ilmiah Kepelatihan. Semarang : IKIP Semarang.

Fardi, Adnan.1989. Hubungan antara kemampuan Loncat raihan dan squat thrusts secara berulang-ulang terhadap kemampuan lari 2400 meter pada siswa-siswi putra kelas satu SMA Kotamadya Padang. Tesis. Jakarta : PPS IKIP Jakarta.

Gallerman, Saul W. 1970. Motivation and Productivity. New Delhi : D.B. Taraporevala Sons \& C.) Private

Handoko. 1996. Motivasi, Daya Penggerak Tingkah Laku. Yogyakarta : Kanisius.

Hasan, Chodijah. 1994. Dimensi Psikologi Pendidikan. Surabaya : Penerbit Ikhlas.

Hasibuan. SP. 1996. Manajemen Sumber Daya Manusia. Dasar dan Sumber Keberhasilan. Jakarta : Bulan Bintang.

Imron, Ali. 1995. Pembinaan Guru di Indonesia. Jakarta: Pustaka Jaya

Kementerian Negara Pemuda dan Olahraga RI. 2005. Sistem Keolahragaan Nasional. Jakarta : Presiden RI.

Kementerian Negara Pemuda dan Olahraga Republik Indonesia. 2005. Penentuan Parameter Tes Pada Pusat Pendidikan dan Pelatihan Pelajar dan Sekolah Khusus Olahraga. Jakarta: Asisten Deputi Pengembangan Sumber Daya manusia Keolahragaan. Deputi Peningkatan Prestasi dan IPTEK Olahraga.

Kosbian, Heru. (2004). Tinjauan tentang Kemampuan Volume Oksigen Maksimal ( $\mathrm{VO}_{2}$ max) (skripsi). Padang: FIK UNP.

Maslow, Abraham H. 1954. Motivation and Personality. New York : Harper and Bross

Mourbas, Iswanelly. 1997. Hubungan Jumlah Konsumsi Makanan Terhadap Indeks Masa Tubuh Orang Dewasa di Kotamadya Padang tahun 1996. tesis. Jakarta : Program Pascasarjana UI.

Rimizowski. 1981. Designing Instructional System. New York. Nich Publishing Company.

Rinawati. (1996). Asuhan Keperawatan pada Klien Tuberkulosis Paru di Unit Rawat Inap Pria di RS. Achmad Muchtar Bukittinggi (skripsi). Padang: Akper Baiturrahmah Padang.

Sajoto, M. 1998. Pembinaan Kondisi Fisik dalam Olahraga. Jakarta : Dirjen Pendidikan Tinggi Depdikbud.

Sardiman, A.M. 1986. Interaksi dan Motivasi Belajar Mengajar. Jakarta : Rajawali.

Slamento. 1995. Belajar dan Faktor-Faktor yang Mempengaruhinya. Jakarta : Rineka Cipta.

Snelbeker, E. Elen. 1974. Learning Theory, instrucsional Theory and Physoeducational Design. New York; Mc. Graw Hill.

Sudijono, Anas. 1998. Pengantar Evaluasi Pendidikan. Jakarta : PT. Raja Grapindo.

Sumosardjono, Sudduso. 1996. Sehat dan Bugar. Jakarta : PT. Gramedia

Soekarman, R. (1989). Dasar Olahraga untuk Pembinaan Pelatih dan Atlet. Jakarta: CV. Haji Mas Agung.

Suratmin. (2007). Pemanfaatan Sumber Daya Alam (SDA) dalam Peningkatan Volume Oksigen Maksimal. Singaraja : PoPari Bali.

Syrifuddin, 1997. Azaz dan Falsafah Penjaskes. Jakarta : Depdikbud.

Tarjab. 1992. Ilmu Jiwa Pendidikan. Jakarta : Karya Abditama. 
Sport Science: Jurnal Sain Olahraga dan Pendidikan Jasmani ISSN 114-562X (Cetak),

ISSN XXXX-XXXX(Online)

http://sportscience.ppj.unp.ac.id/index.php/jss/index

Umar. 2008. Fisiologi Olahraga. Padang : FIK UNP.

Winkel. 1984. Psikologi Pendidikan. Jakarta : Remadja Rosdakarya.

Wirartha, I Made. (2006). Pedoman Penulisan Usulan Penelitian, Skripsi, dan Tesis. Yogyakarta: CV. Andi Offset. 